\title{
High p-Smad2 expression in stromal fibroblasts predicts poor survival in patients with clinical stage I to IIIA non-small cell lung cancer
}

\author{
Yongbing Chen ${ }^{1}$, Pengfei Xing ${ }^{2}$, Yuanyuan Chen ${ }^{2}$, Li Zou ${ }^{2}$, Yongsheng Zhang ${ }^{3}$, Feng Li $i^{3}$ and Xueguan Lu ${ }^{2 *}$
}

\begin{abstract}
Background: Increasing evidence indicates that the TGF $\beta / S$ mad signaling pathway plays a prominent role in tumor initiation, progression, and metastasis. Therefore, we investigate the expression of $\mathrm{p}-\mathrm{Smad} 2$ in surgical resection specimens from non-small cell lung cancer, and evaluate the prognostic significance of p-Smad2 expression in stromal fibroblasts and cancer cells for patients with clinical stage I to IIIA non-small cell lung cancer.

Methods: The immunohistochemical expression of p-Smad2 was evaluated in 78 formalin-fixed paraffin-embedded surgical resection specimens from clinical stage I to IIIA non-small cell lung cancer. Correlations between p-Smad2 expression and clinicopathologic characteristics were determined by Chi-square test. The prognostic significance of p-Smad2 expression in stromal fibroblasts and cancer cells with regard to overall survival was determined by Kaplan-Meier.
\end{abstract}

Results: There were 38.5\% (30/78) and 92.3\% (72/78) patients with high p-Smad2 expression in stromal fibroblasts and cancer cells, respectively. There was a positive correlation between the p-Smad2 expression level in stromal fibroblasts and the $p$-Smad2 expression level in cancer cells $\left(X^{2}=4.176, P=0.045\right)$. No significant correlation of p-Smad2 expression in stromal fibroblasts or cancer cells with any of clinicopathologic characteristics was found. The 3-year overall survival rates with low and high p-Smad2 expression in stromal fibroblasts were $53.7 \%$ and $37.7 \%$, respectively $\left(x^{2}=3.86, P=0.049\right)$. No significant association was found between low and high $p$-Smad2 expression in cancer cells with respect to overall survival, respectively $\left(X^{2}=0.34, P=0.562\right)$.

Conclusions: The results suggested that high $\mathrm{p}-\mathrm{Smad} 2$ expression in stromal fibroblasts predicted poor survival in patients with clinical stage I to IIIA non-small cell lung cancer.

Keywords: lung cancer, stromal fibroblasts, p-Smad2, prognosis

\section{Background}

Non-small cell lung cancer (NSCLC) accounts for $80 \%$ of all lung cancers and is the most common cause of cancer-related death worldwide [1,2]. In spite of recent advances in surgical techniques, chemotherapy, radiotherapy and many kinds of new strategies of treatment, long-term survival is achieved in only 5 to $10 \%$ of NSCLC patients [3]. The molecular mechanisms involved in lung carcinogenesis are associated with dysregulation of many signaling pathways. Among these,

\footnotetext{
* Correspondence: luxueguan@163.com

2Department of Oncology \& Radiotherapy, the Second Affiliated Hospital of Soochow University, 1055 Sanxiang Road, Suzhou 215004, Jiangsu Province, P.R. China

Full list of author information is available at the end of the article
}

transforming growth factor- $\beta$ (TGF- $\beta$ ) signaling plays an important role in development and progression of lung cancer [4-6]. TGF- $\beta$ displays a dual role in cancer development. In early tumorigenesis, it functions as a tumor suppressor, whereas in later stages of tumor progression, it acts as a tumor promoter [7]. TGF- $\beta$ is synthesized as a latent, extracellular matrix (ECM)-bound molecule, which is activated via proteolytic and nonproteolytic pathways. Activated TGF- $\beta$ binds to TGF- $\beta$ type-II receptor (T $\beta$ RII), which subsequently recruits and transphosphorylates the type ITGF- $\beta$ receptor activin receptor-like kinase (ALK)-5. Subsequently, intracellular signaling is mediated by the family of Smad proteins 
comprising eight members (Smad [1-8]). TGF- $\beta$ receptoractivated Smad2 and Smad3 form heteromeric complexes with the common mediator Smad4 and then translocate to the nucleus where they act as ligand-induced transcription regulators of target genes $[8,9]$.

In recent years, increasing evidence indicates that the progression of tumors toward a malignant phenotype does not only depend on the cell-autonomous properties of cancer cells themselves but is also deeply influenced by tumor stroma [10]. The activated stromal fibroblasts, termed cancer-associated fibroblasts (CAFs), play a prominent role in tumor initiation, progression, and metastasis $[11,12]$. TGF- $\beta$ is implicated in the activation of tumor stromal fibroblasts, leading to the generation of CAFs and to promoting tumor stromal formation through the TGF $\beta /$ Smad signaling pathway [13-15].

Several previous studies have demonstrated that Smad2 expression level in cancer cells appeared to be correlated with tumor development and prognosis in patients with gastric carcinoma, glioma, breast cancer, colorectal cancer, and esophageal squamous cell carcinoma $[16,17]$. However, not much is known regarding the prognostic value of Smad2 expression in lung cancer cells. In addition, there is especially a lack of evidence about the prognostic significance of Smad2 expression in stromal fibroblasts of lung cancer. In the present study, therefore, we investigated the $\mathrm{p}$-Smad2 expression in surgical resection specimens from NSCLC to evaluate the prognostic significance of $\mathrm{p}-\mathrm{Smad} 2$ expression in stromal fibroblasts and cancer cells for patients with clinical stage I to IIIA NSCLC.

\section{Methods}

Patients and surgical resection specimen selection

The paraffin-embedded postoperative tumor specimens were obtained from the tissue bank in the Department of Pathology, the Second Affiliated Hospital of Soochow University, between January of 2009 and June of 2011. We retrospectively recruited 78 tumor specimens from patients with clinical stage I to IIIA NSCLC. The ethics committee of the Second Affiliated Hospital of Soochow University approved the current project, and waived the need for written informed consent.

The main characteristics of the 78 patients with clinical stage I to IIIA NSCLC were summarized in Table 1. Ages of the patients in this study range from 41 to 81 years (median, 63 years). According to the AJCC/ UICC (6th edition), there were 20 patients with stage I, 9 patients with stage II, and 49 patients with stage IIIA. All patients underwent curative resection. Systemic adjuvant treatment was administered to 64 patients. The chemotherapeutic regimen used was a cisplatin-based doublet. Seventeen patients received thoracic postoperative radiotherapy.
Table 1 Patient characteristics

\begin{tabular}{|c|c|}
\hline Characteristic & $\begin{array}{l}\text { Number of } \\
\text { patients (\%) }\end{array}$ \\
\hline Patients & $78(100.0)$ \\
\hline \multicolumn{2}{|c|}{ Median age $=63$ years (range 41 to 81 ) } \\
\hline \multicolumn{2}{|l|}{ Gender } \\
\hline Male & $55(70.5)$ \\
\hline Female & $23(29.5)$ \\
\hline \multicolumn{2}{|l|}{ Pathologic type } \\
\hline Squamous carcinoma & $41(52.6)$ \\
\hline Adenocarcinoma & $29(37.2)$ \\
\hline Adenosquamous carcinoma & $3(3.8)$ \\
\hline Large cell carcinoma & $5(6.4)$ \\
\hline \multicolumn{2}{|l|}{ Pathologic differentiation } \\
\hline High & $5(6.4)$ \\
\hline Median & $50(64.1)$ \\
\hline Low & $23(29.5)$ \\
\hline \multicolumn{2}{|l|}{ Clinical Stage* } \\
\hline I & $20(25.6)$ \\
\hline$\|$ & $9(11.5)$ \\
\hline$\| I I A$ & $49(62.9)$ \\
\hline \multicolumn{2}{|c|}{ Treatment modality - Curative resection } \\
\hline Yes & $78(100.0)$ \\
\hline No & $0(0)$ \\
\hline \multicolumn{2}{|c|}{ Treatment modality - Adjuvant chemotherapy } \\
\hline Yes & $64(82.1)$ \\
\hline No & $14(17.9)$ \\
\hline \multicolumn{2}{|c|}{ Treatment modality - Postoperative radiotherapy } \\
\hline Yes & $17(21.8)$ \\
\hline No & $61(78.2)$ \\
\hline
\end{tabular}

${ }^{*}$ According to Union for International Cancer Control/American Joint Committee on Cancer (6th edition) stage system.

\section{Immunohistochemistry}

Serial slides, each 3-um thick, were cut from paraffinembedded tissue. One slide was stained with hematoxylin and eosin (HE). Immunohistochemical staining was performed on another slide, using the two-step procedure. The anti-human p-Smad2 rabbit polyclonal antibody (Ser465/467) (Chemicon, Billerica, MA, USA; diluted 1: 500) was used. After de-paraffinization and hydration, the slides were subjected to antigen retrieval by pressurecooking for 30 minutes. Endogenous peroxidase activity was neutralized using peroxide block placement on the slides for 15 minutes at room temperature. The slides were then incubated with anti-p-Smad2 antibody for 40 minutes at $4^{\circ} \mathrm{C}$. This was followed by incubation with peroxidase-conjugated polymer (ChemMate EnVision/ HRP; Gene Tech, Shanghai, China) for 30 minutes at room temperature. The chromogen reaction was 
developed in 3,3'-diaminobenzidine (DAB; Gene Tech, Shanghai, China) tetrahydrochloride for 10 minutes. Finally, hematoxylin was used as a light nuclear counterstain. The negative control used was an IgG2b isotype antibody (Dako), ensuring the same concentration of immunoglobins as for anti-p-Smad2.

\section{Assessment of $\mathrm{p}$-Smad2 expression}

All slides were evaluated independently by two experienced pathologists (Li F and Zhang Y). Ten high-power fields were selected randomly for each slide. The expression levels of each marker in cancer cells and stromal fibroblasts were independently evaluated. The percentage of positive-staining cells were graded on a scale of 0to 3 , with less than $5 \%$ positive-staining cells as grade 0,5 to $25 \%$ as grade 1,26 to $50 \%$ as grade 2 , and more than $50 \%$ as grade 3 . The intensity of staining was also graded on a scale of 0 to 2 , with negative to weak intensity as grade 0 , weak to moderate intensity as grade 1 , and moderate to strong intensity as grade 2 . After that, the percentage score was multiplied by the intensity score. A final score between 0 and 2 was defined as low expression, and a score higher than 2 was defined as high expression.

\section{Statistical analysis}

The association between $\mathrm{p}$-Smad2 expression in cancer cells or stromal fibroblasts and clincopathologic characteristics was examined with a Chi-square test. Overall survival (OS) rates were performed by the Kaplan-Meier method and log-rank test. Overall survival duration was defined from the day of surgery to the day of death or last follow-up. For all tests, a two-sided $P<0.05$ was considered significant.

\section{Results}

\section{Expression of $\mathrm{p}-\mathrm{Smad} 2$ in stromal fibroblasts and cancer} cells

The expression of p-Smad2 was confined to the nucleus. The expression level of p-Smad2 in stromal fibroblasts ranged from $12.5 \%$ to $85.8 \%$, and its expression level in cancer cells ranged from $19.3 \%$ to $94.2 \%$. There were $38.5 \%(30 / 78)$ and $92.3 \%(72 / 78)$ patients with high pSmad2 expression in stromal fibroblasts and cancer cells, respectively (Figure 1 ). The analysis revealed that there was a positive correlation between the $\mathrm{p}$-Smad2 expression level in stromal fibroblasts and the $\mathrm{p}$-Smad2 expression level in cancer cells $\left(\chi^{2}=4.176, P=0.045\right)$. With regard to age, gender, clinical stage, pathologic type and differentiation, there was no significant correlation of $\mathrm{p}$ Smad2 expression in stromal fibroblasts or cancer cells with any of clinicopathologic characteristics (Table 2).

\section{Prognosis analysis}

The median duration of follow-up for these patients was 26 months (range, 1 to 55 months). The Kaplan-Meier plots showed that the 3-year OS rate of all patients was $47.6 \%$. The 3-year OS rates with clinical stage I + II and IIIA were $68.0 \%$ and $32.8 \%$, respectively $\left(\chi^{2}=6.27, P=\right.$ 0.012; Figure 2a). The 3 -year OS rates with low and high p-Smad2 expression in stromal fibroblasts were 53.7\% and $37.7 \%$, respectively $\left(\chi^{2}=3.86, P=0.049\right.$; Figure $\left.2 \mathrm{~b}\right)$.

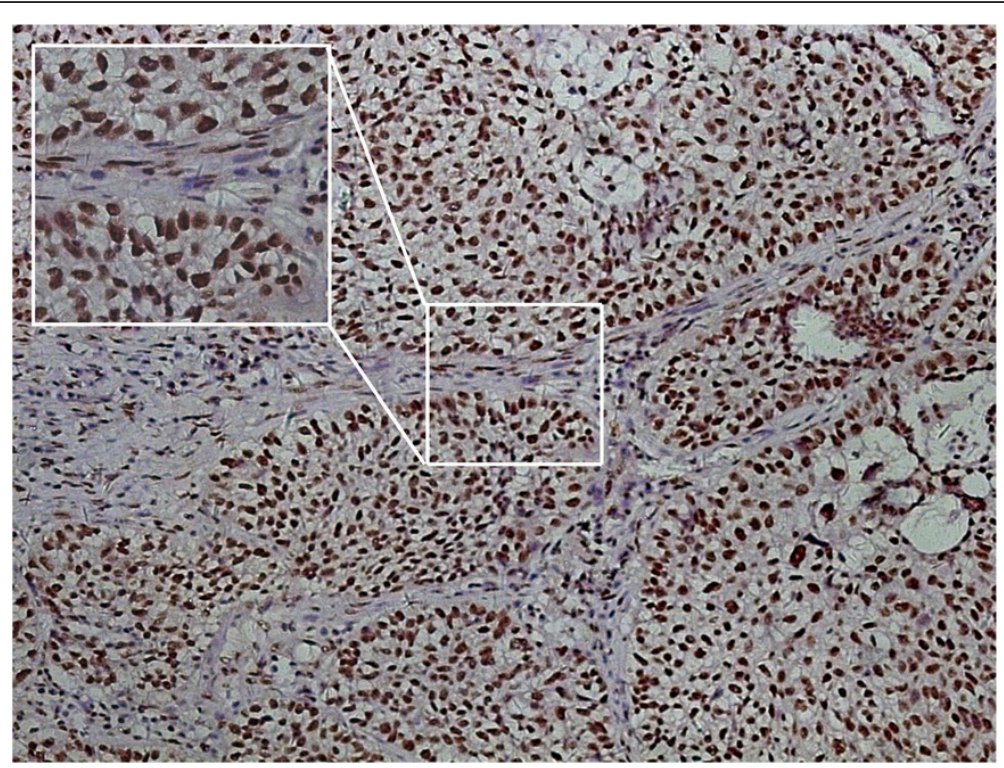

Figure 1 Expression of p-Smad2 in stromal fibroblasts and in cancer cells by immunohistochemistry in non-small cell lung cancer (NSCLC) (magnification $\times 200$ ). 
Table 2 Association between p-Smad2 expression in cancer cells or stromal fibroblasts and clinicopathologic characteristics

\begin{tabular}{|c|c|c|c|c|c|c|c|}
\hline \multirow[b]{2}{*}{ Variables } & \multirow[b]{2}{*}{ Number of patients } & \multicolumn{3}{|c|}{ p-Smad2 expression in cancer cells } & \multicolumn{3}{|c|}{ p-Smad2 expression in stromal fibroblasts } \\
\hline & & Low (\%) & High (\%) & $P$ & Low (\%) & High (\%) & $P$ \\
\hline \multicolumn{8}{|l|}{ Gender } \\
\hline Male & 55 & $5(9.1)$ & $50(90.9)$ & 0.473 & $32(58.2)$ & $23(41.8)$ & 0.346 \\
\hline Female & 23 & $1(4.3)$ & $22(95.7)$ & & $16(69.6)$ & $7(30.4)$ & \\
\hline \multicolumn{8}{|l|}{ Age (years) } \\
\hline$\leq 63$ & 41 & $2(4.9)$ & $39(95.1)$ & 0.326 & $23(56.1)$ & $18(43.9)$ & 0.298 \\
\hline$>63$ & 37 & $4(10.8)$ & $33(89.2)$ & & $25(67.6)$ & $12(32.4)$ & \\
\hline \multicolumn{8}{|l|}{ Pathologic type } \\
\hline Squamous carcinoma & 41 & $2(4.9)$ & $39(95.1)$ & 0.560 & $24(58.5)$ & $17(41.5)$ & 0.605 \\
\hline Adenocarcinoma & 29 & $3(10.3)$ & $26(89.7)$ & & $20(69.0)$ & $9(31.0)$ & \\
\hline Adenosquamous carcinoma & 3 & $0(0)$ & $3(100.0)$ & & $2(66.7)$ & $1(33.3)$ & \\
\hline Large cell carcinoma & 5 & $1(20.0)$ & $4(80.0)$ & & $2(40.0)$ & $3(60.0)$ & \\
\hline \multicolumn{8}{|l|}{ Pathologic differentiation } \\
\hline High & 5 & $0(0)$ & $5(100.0)$ & 0.562 & $4(80.0)$ & $1(20.0)$ & 0.679 \\
\hline Median & 50 & $5(10.0)$ & $45(90.0)$ & & $30(60.0)$ & $20(40.0)$ & \\
\hline Low & 23 & $1(4.3)$ & $22(95.7)$ & & $14(60.9)$ & $9(39.1)$ & \\
\hline \multicolumn{8}{|l|}{ Clinical Stage* } \\
\hline $\mid+\|$ & 29 & $4(13.8)$ & $25(86.2)$ & 0.120 & $20(69.0)$ & $9(31.0)$ & 0.300 \\
\hline$\| \mathrm{A}$ & 49 & $2(4.1)$ & 47 (95.9) & & $28(57.1)$ & $21(42.9)$ & \\
\hline
\end{tabular}

*According to Union for International Cancer Control/American Joint Committee on Cancer (6th edition) stage system.

However, no significant association was found between low and high p-Smad2 expression in cancer cells with respect to OS, respectively $\left(\chi^{2}=0.34, P=0.562\right)$.

\section{Discussion}

Because p-Smad2 is a primary step and intracellular signaling effector for the mediation of intracellular signaling of TGF $\beta$ [18], we focused our study on p-Smad2 expression on NSCLC. The present study demonstrated that $\mathrm{p}-\mathrm{Smad} 2$ expression was confined to the nucleus, and its expression level in cancer cells was high in 72 (92.3\%) of 78 NSCLC. However, Shinto et al. [16] found that the high expression level of p-Smad2 in cancer cells was existed in 63 (47\%) of 135 gastric carcinomas. de Kruijf et al. [10] found that 129 (26.9\%) of 505 breast cancers had high nuclear expression of p-Smad2 in cancer cells. These results suggest that the expression level of $\mathrm{p}$-Smad2 in cancer cells is associated with tumor type. Recently, a few studies have demonstrated that Smad2 expression level in cancer cells is correlated with tumor development and prognosis. Previous studies on esophageal squamous cell carcinoma, breast cancer and colorectal cancer demonstrated that loss of Smad2 expression was correlated with tumor development and poor prognosis [19-21]. Conversely, Shinto et al. [16] found that the prognosis for $\mathrm{p}$-Smad2-high patients with advanced stage gastric carcinoma was significantly poorer than that of p-Smad2-low patients. de Kruijf et al. [10] found that high expression of $\mathrm{p}-\mathrm{Smad} 2$ was substantially associated with a worse prognosis in breast cancer. Similarly, the positive $\mathrm{p}-\mathrm{Smad} 2$ expression was reported to be correlated with tumor proliferation and poor prognosis in a study of 52 patients with glioma [22]. At the same time, some studies demonstrated that p-Smad2 expression level was not related to the prognosis in patients with renal clear cell carcinoma and colorectal cancer $[23,24]$. In the present study, we also found that the expression level of p-Smad2 in cancer cells was not associated with any of clinicopathologic characteristics and 3-year overall survival in patients with clinical stage I to IIIA NSCLC. These studies suggest that the results are inconsistent, even completely opposite in the same tumor type, and the further study is needed.

In recent years, increasing evidence indicates that activating TGF $\beta /$ Smad signaling pathway promotes the generation of CAFs and tumor stromal formation, and plays prominent roles in tumor initiation, progression, and metastasis [11-15]. So we further investigated pSmad2 expression in stromal fibroblasts and its prognostic significance in NSCLC. The results found that $38.5 \%$ (30/78) patients with NSCLC had high p-Smad2 expression in stromal fibroblasts. Hawinkels et al. [9] found that $89 \%$ and $42 \%$ of 88 patients with colorectal cancer were observed with nuclear $\mathrm{p}$-Smad2 expression 
a
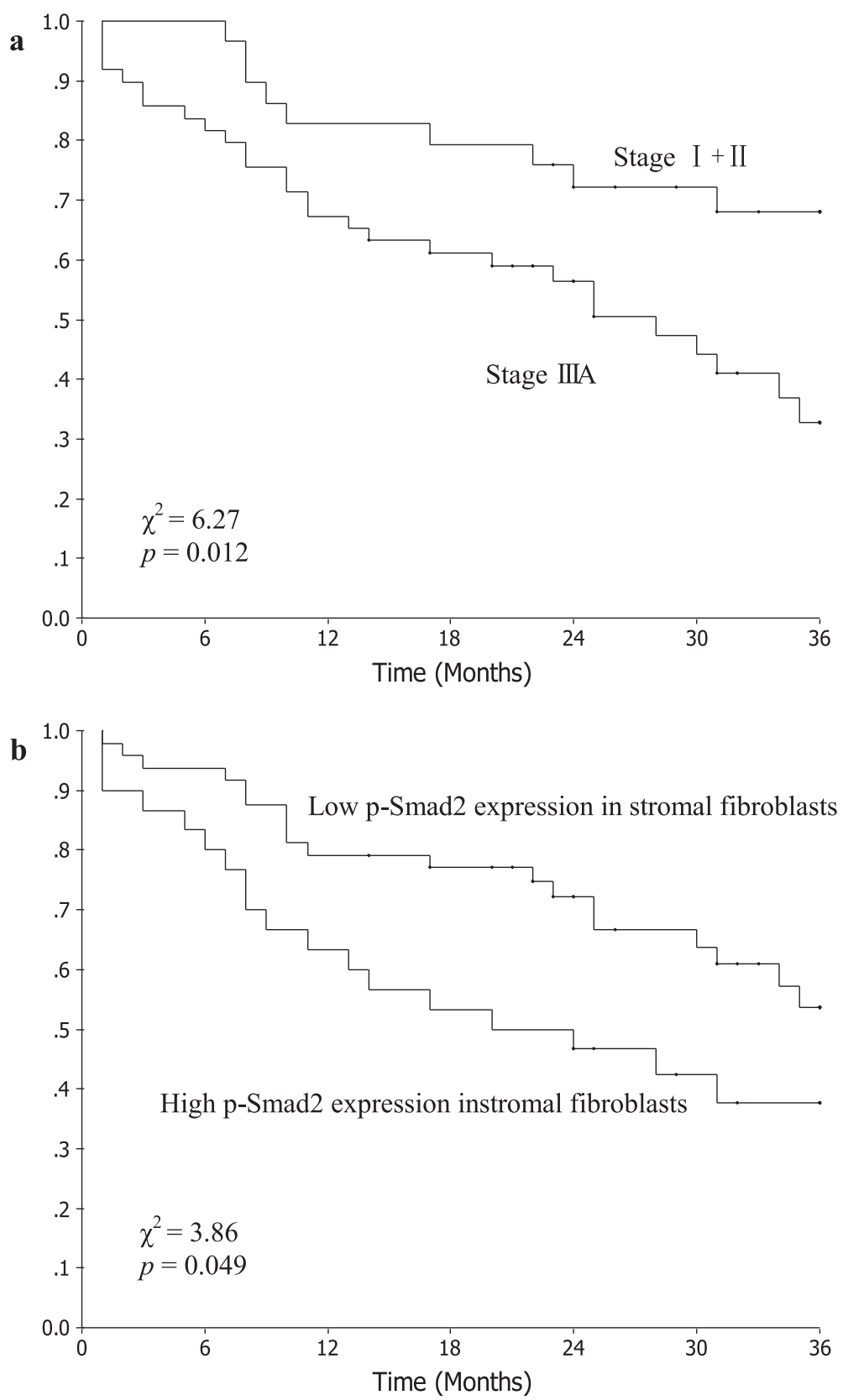

Figure 2 Kaplan-Meier curves for patients with clinical stage I to IIIA non-small cell lung cancer (NSCLC). a. different clinical stage groups; b. different $\mathrm{p}$-Smad2 expression groups.

in stromal fibroblasts and cancer cells. Moreover, we also found that there was a positive correlation between the $\mathrm{p}$-Smad2 expression level in stromal fibroblasts and the p-Smad2 expression level in cancer cells $(P=0.045)$. The high $\mathrm{p}$-Smad2 expression in stromal fibroblast was associated with a trend for poor overall survival in patients with clinical stage I to IIIA NSCLC. As we all know, this is the first report that focuses on prognostic significance of $\mathrm{p}$-Smad2 expression in stromal fibroblasts.

\section{Conclusions}

In conclusion, the results suggest that high p-Smad2 expression in stromal fibroblasts predicted poor survival in patients with clinical stage I to IIIA NSCLC. However, this study is limited by the relatively small number of patients, and more and larger studies are required.

\section{Abbreviations}

ALK: activin receptor-like kinase; CAFs: cancer-associated fibroblasts; T $\beta R$ II: TGF- $\beta$ type-II receptor; NSCLC: non-small cell lung cancer; OS: overall survival; TGF- $\beta$ : transforming growth factor- $\beta$. 


\section{Competing interests}

The authors declare that they have no competing interests.

\section{Authors' contributions}

YoC and $X L$ designed the study, analyzed the data, and wrote the manuscript. PX carried out the $\mathrm{HC}$. YZ and FL read and analyzed the $\mathrm{HC}$ slides. YuC and LZ collected the clinical data. All authors read and approved the final manuscript.

\section{Acknowledgments}

This study was supported by grants from the Priority Academic Program Development of Jiangsu Higher Education Institutions and Jiangsu Province's Key Medical Person (RC2011144).

\section{Author details}

${ }^{1}$ Department of Thoracic Surgery, the Second Affiliated Hospital of Soochow University, 1055 Sanxiang Road, Suzhou 215004, Jiangsu Province, P.R. China. ${ }^{2}$ Department of Oncology \& Radiotherapy, the Second Affiliated Hospital of Soochow University, 1055 Sanxiang Road, Suzhou 215004, Jiangsu Province, P.R. China. ${ }^{3}$ Department of Pathology, the Second Affiliated Hospital of Soochow University, 1055 Sanxiang Road, Suzhou 215004, Jiangsu Province, P.R. China.

Received: 28 April 2014 Accepted: 20 October 2014

Published: 5 November 2014

\section{References}

1. Siegel R, Naishadham D, Jemal A: Cancer statistics, 2012. CA Cancer J Clin 2012, 62:10-29.

2. Ferlay J, Shin HR, Bray F, Forman D, Mathers C, Parkin DM: Estimates of worldwide burden of cancer in 2008: GLOBOCAN 2008. Int J Cancer 2010, 127:2893-2917.

3. Haithcock BE, Stinchcombe TE, Socinski MA: Treatment of surgically resectable non-small-cell lung cancer in elderly patients. Clin Lung Cancer 2009, 10:405-409.

4. Shintani Y, Abulaiti A, Kimura T, Funaki S, Nakagiri T, Inoue M, Sawabata N, Minami M, Morii E, Okumura M: Pulmonary fibroblasts induce epithelial mesenchymal transition and some characteristics of stem cells in non-small cell lung cancer. Ann Thorac Surg 2013, 96:425-433.

5. Pajares MJ, Agorreta J, Salvo E, Behrens C, Wistuba II, Montuenga LM, Pio R, Rouzaut A: TGFB1 expression is an independent predictor of survival in adjuvant-treated lung squamous cell carcinoma patients. $\mathrm{Br} J$ Cancer 2014, 110:1545-1551.

6. Kim CH, Park SY, Yoo J: Expression of transforming growth factor $\beta 1$ and E-Cadherin proteins in pulmonary adenocarcinoma: its significance in tumor progression. Cancer Res Treat 2013, 45:118-125.

7. Perttu MC, Martikainen PM, Huhtala HSA, Blauer M, Tammela TLJ, Tuohimaa PJ, Syvala H: Altered levels of Smad2 and Smad4 are associated with human prostate carcinogenesis. Prostate Cancer P D 2006, 9:185-189.

8. Feng XH, Derynck R: Specificity and versatility in TGF-signaling through smads. Ann Rev Cell Dev Biol 2005, 21:659-693.

9. Hawinkels LJAC, Paauwe M, Verspage HW, Wiercinska E, van der Zon JM, van der Ploeg K, Koelin PJ, Lindeman JHN, Mesker W, ten Dijke P, Sier CFM: Interaction with colon cancer cells hyperactivates TGF- $\beta$ signaling in cancer-associated fibroblasts. Oncogene 2014, 33:97-107.

10. de Kruijf EM, Dekker TJA, Hawinkels LJAC, Putter H, Smit VTHBM, Kroep JR, Kuppen PJK, van de Velde CJH, ten Dijke P, Tollenarr RAEM, Mesker WE: The prognostic role of TGF- $\beta$ signaling pathway in breast cancer patients. Ann Oncol 2013, 24:384-390.

11. Cirri P, Chiarugi P: Cancer-associated-fibroblasts and tumor cells: a diabolic liaison driving cancer progression. Cancer Metastasis Rev 2012, 31:195-208.

12. Mantoni TS, Lunardi SL, Al-Assar O, Masamune A, Brunner TB: Pancreatic stellate cells radioprotect pancreatic cancer cells through $\beta 1$-integrin signaling. Cancer Res 2011, 71:3453-3458.

13. Hazelbag S, Gorter A, Kenter GG, van den Broek L, Fleuren G: Transforming growth factor- $\beta 1$ induces tumor stroma and reduces tumor infiltrate in cervical cancer. Hum Pathol 2002, 33:1193-1199.

14. Xu Z, Wang S, Wu M, Zeng W, Wang X, Dong Z: TGF- $\beta 1$ and HGF protein secretion by esophageal squamous epithelial cells and stromal fibroblasts in oesophageal carcinogenesis. Oncol Lett 2013, 6:401-406.
15. Peng Y, Li Z, Li Z: GRP78 secreted by tumor cells stimulates differentiation of bone marrow mesenchymal stem cells to cancer-associated fibroblasts. Biochem Biophys Res Commun 2013, 440:558-563.

16. Shinto O, Yashiro M, Toyokawa T, Nishii T, Kaizaki R, Matsuzaki T, Noda S, Kubo N, Tanaka H, Doi Y, Ohira M, Muguruma K, Sawada T, Hirakawa K: Phosphorylated Smad2 in advanced stage gastric carcinoma. BMC Cancer 2010, 10:652-659.

17. Wu Y, Li Q, Zhou X, Yu J, Mu Y, Munker S, Xu C, Shen Z, Mullenbach R, Liu Y, Li L, Gretz N, Zieker D, Li J, Matsuzaki K, Li Y, Dooley S, Weng H: Decreased levels of active SMAD2 correlate with poor prognosis in gastric cancer. PLoS One 2012, 7:e35684.

18. Miyazono K, Suzuki H, Imamura T: Regulation of TGF-beta signaling and its roles in progression of tumors. Cancer Sci 2003, 94:230-234.

19. Fukuchi M, Nakajima M, Miyazaki T, Masuda N, Osawa H, Manda R, Tsukada K, Kato $\mathrm{H}$, Kuwano H: Lack of activated Smad2 in transforming growth factor-beta signaling is an unfavorable prognostic factor in patients with esophageal squamous cell carcinoma. J Surg Oncol 2006, 94:51-56.

20. Xie W, Mertens JC, Reiss DJ, Rimm DL, Camp RL, Haffty BG, Reiss M: Alterations of Smad signaling in human breast carcinoma are associated with poor outcome: a tissue microarray study. Cancer Res 2002, 62:497-505

21. Xie W, Rimm DL, Lin Y, Shih WJ, Reiss M: Loss of Smad signaling in human colorectal cancer is associated with advanced disease and poor prognosis. Cancer J 2003, 9:302-312.

22. Bruna A, Darken RS, Rojo F, Ocana A, Penuelas S, Arias A, Paris R, Tortosa A, Mora J, Baselga J, Seoane J: High TGF beta-Smad activity confers poor prognosis in glioma patients and promotes cell proliferation depending on the methylation of the PDGF-B gene. Cancer Cell 2007, 11:147-160.

23. Park JH, Lee C, Suh JH, Chae JY, Moon KC: Nuclear expression of Smad proteins and its prognostic significance in clear cell renal cell carcinoma. Hum Pathol 2013, 44:2047-2054.

24. Voorneveld PW, Jacobs RJ, De Miranda NF, Morreau H, van Noesel CJ, Offerhaus GJ, Kodach LL, Hardwick JC: Evaluation of the prognostic value of pSMAD immunohistochemistry in colorectal cancer. Eur J Cancer Prev 2013, 22:420-424.

doi:10.1186/1477-7819-12-328

Cite this article as: Chen et al:: High p-Smad2 expression in stromal fibroblasts predicts poor survival in patients with clinical stage I to IIIA non-small cell lung cancer. World Journal of Surgical Oncology 2014 12:328.

\section{Submit your next manuscript to BioMed Central and take full advantage of:}

- Convenient online submission

- Thorough peer review

- No space constraints or color figure charges

- Immediate publication on acceptance

- Inclusion in PubMed, CAS, Scopus and Google Scholar

- Research which is freely available for redistribution 